\title{
KEPENULISAN CERPEN SANTRI PONDOK PESANTREN PUTRI TEBUIRENG DENGAN STRATEGI PSIKOLIGI KOMUNITAS
}

\author{
${ }^{1}$ Alfian Setya Nugraha, ${ }^{2}$ Rusli Ilham Fadli, ${ }^{3}$ Resdianto Permata Raharjo, ${ }^{4}$ Raras Hafiidah Sari, \\ ${ }^{5}$ Agus Sulton \\ 1,2,3,4,5 Pendidikan Bahasa dan Sastra Indonesia FIP, Universitas Hasyim Asy’ari Tebuireng Jombang \\ ${ }^{1}$ alfiansetyanugraha@gmail.com
}

\begin{abstract}
The purpose of this community service activity is to assist students in understanding the writing of short stories in Pondok Putri Tebuireng Islamic Boarding School in Jombang. This is one of the obligations of educators in order to solve social problems that have occurred in the community in the last period. Community service activities are carried out using the lecture method and discussion of the opinion writing, short stories, and reviews. In addition, participants were also given the opportunity to discuss with the speakers and other participants.
\end{abstract}

Keywords: short stories, female students, community psychology

\begin{abstract}
Abstrak
Tujuan diadakannya kegiatan pengabdian kepada masyarakat ini adalah untuk mendampingi santriwati dalam memahami kepenulisan cerpen yang ada di Pondok Putri Pesantren Tebuireng Jombang. Kali ini merupakan salah satu kewajiban pendidik dalam rangka menyelesaikan permasalahan sosial yang dalam kurun waktu terakhir ini terjadi di masyarakat. Kegiatan pengabdian kepada masyarakat ini dilaksanakan dengan menggunakan metode ceramah dan diskusi tentang kepenulisan opini, cerpen, dan resensi. Selain itu, peserta juga diberikan kesempatan untuk berdiskusi dengan para pemateri dan peserta yang lain.
\end{abstract}

Kata kunci: cerpen, santri putri, psikologi komunitas

\section{PENDAHULUAN}

Amanat Undang-Undang Nomor 20 Tahun 2003 tentang Sistem Pendidikan Nasional menyebutkan bahwa perguruan tinggi berkewajiban menyelenggarakan pendidikan, penelitian, dan pengabdian kepada masyarakat (Pasal 20 Ayat 2). Pelaksanaan pengabdian masyarakat sebagaimana dimaksud diatur dalam Undang-Undang Pendidikan Tinggi No.12 Tahun 2012, yaitu pengabdian masyarakat adalah kegiatan sivitas akademika yang memanfaatkan ilmu pengetahuan dan teknologi untuk memajukan kesejahteraan masyarakat dan mencerdaskan kehidupan bangsa.

Program pengabdian kepada masyarakat merupakan salah satu program yang wajib dilaksanakan, baik oleh dosen maupun oleh mahasiswa, dengan berlandaskan pada prinsipprinsip:

kompetensi akademik, jiwa kewirausahaan

(entrepreneurship), dan profesional, sehingga dapat menghasilkan program pengabdian kepada masyarakat yang bermutu, relevan, dan sinergis dalam meningkatkan pemberdayaan masyarakat.

Pengabdian kepada masyarakat merupakan salah satu dharma atau tugas pokok dari suatu perguruan tinggi, termasuk disamping dharma pendidikan dan pengajaran serta dharma penelitian. Pelaksanaan dharma pengabdian kepada masyarakat yang dalam realisasinya juga melibatkan dua dharma lainnya. Pengabdian masyarakat merupakan kegiatan yang memanfaatkan ilmu pengetahuan dalam upaya memberikan sumbangan demi kemajuan masyarakat. Pengertian mengenai pengabdian masyarakat secara filosofis sesungguhnya dapat berkembang dan dikembangkan sesuai dengan 
persepsi dan tergantung pada dimensi ruang dan waktu.

Guna melaksanakan amanat undangundang tersebut dan merealisasikan visi Universitas Hasyim Asy'ari Tebuireng Jombang, khususnya dalam pelaksanaan pengabdian pada masyarakat agar dapat terlaksana secara efektif, maka diperlukan kegiatan pengabdian masyarakat yang dilakukan dalam bentuk kegiatan Workshop Kepenulisan (Opini, Cerpen, dan Resensi)dengan menggunakan pendekatan psikologi komunitas yang dilaksanakan di Masjid Ulul Albab Kawasan Pondok Putri Pesantren Tebuireng pada tanggal 15, 22, dan 29 Maret 2019.

Berdasarkan uraian sebelumnya, dapat dirumuskan permasalahan sebagai berikut.

1. Bagaimana penulisan cerpen dengan pendekatan psikologi komunitas?

2. Bagaimana menentukan isi serta struktur penulisan cerpen dengan pendekatan psikologi komunitas?

3. Bagaimana implikasi pembuatan Cerpen melalui psikologi komunitas?

Mengacu pada permasalahan yang telah diuraikan sebelumnya, solusi diadakannya kegiatan pengabdian kepada masyarakat ini adalah memberikan kesadaran untuk meningkatkan minat menulis cerpen, memberikan kesadaran untuk meningkatkan minat menulis cerpen, dan mendorong munculnya penulis cerpen yang handal.

Luaran dari kegiatan pengabdian kepada masyarakat ini dijabarkan pada tabel di bawah ini.

\begin{tabular}{|c|l|c|}
\hline No. & \multicolumn{1}{|c|}{ Jenis Luaran } & $\begin{array}{c}\text { Targer } \\
\text { Luaran }\end{array}$ \\
\hline 1. & Jurnal & Ada \\
\hline 2. & $\begin{array}{l}\text { Peningkatan daya saing } \\
\text { (peningkatan kualitas, } \\
\text { kuantitas, serta nilai } \\
\text { tambah barang, jasa, } \\
\text { diversifikasi produk, atau } \\
\text { sumber daya lainnya })\end{array}$ & $\begin{array}{l}\text { Tidak } \\
\text { Ada }\end{array}$ \\
\hline 3. & $\begin{array}{l}\text { Peningkatan penerapan } \\
\text { iptek di masyarakat } \\
\text { (mekanisasi, IT, dan } \\
\text { manajemen) }\end{array}$ & $\begin{array}{l}\text { Tidak } \\
\text { Ada }\end{array}$ \\
\hline 5. & Buku & Ada \\
\hline
\end{tabular}

\section{METODE}

Kegiatan pengabdian kepada masyarakat ini dilaksanakan dengan menggunakan metode ceramah dan diskusi tentang kepenulisan opini, cerpen, dan resensi. Selain itu, peserta juga diberikan kesempatan untuk berdiskusi dengan para pemateri dan peserta yang lain. Diskusi dilaksanakan secara terpisah. Hal ini diperuntukkan bagi para peserta, guna mempermudah pelatihan. Diskusi tersebut juga bertujuan untuk lebih mempermudah menerapkan metode psikologi komunitas, hal ini menjadikan kedekatan serta pengenalan karakter peserta dengan pemateri. Dengan adanya kedekatan tersebut menjadikan pemateri lebih mudah dalam menggali potensi serta kreativitas peserta dalam hal ini para santriwati pondok pesantren putri Tebuireng.

Sebelum kegiatan pengabdian kepada masyarakat ini dilaksanakan, maka dilakukan persiapan yaitu:

Persiapan pertama yaitu mempersiapkan materi tentang Workshop Kepenulisan (Opini, Cerpen, dan Resensi). Materi perlu disiapkan guna memperlancar proses pelatihan kepada peserta.

Persiapan berikutnya menentukan waktu pelaksanaan kegiatan yang pada kesempatan ini banyak menemukan kendala diantaranya harus memadukan waktu para pemateri dan peserta. Di samping itu kita harus menyesuaikan dengan jadwal pondok 
pesantren yang mana sasaran kita merupakan santriwati pondok putri Tebuireng Jombang.

Kegiatan pengabdian kepada masyarakat ini dilaksanakan selama 3 (tiga) hari, tempat yang digunakan beralamat di Jalan Irian Jaya 10 Cukir Diwek Kabupaten Jombang, tepatnya di Masjid Ulul Albab Kawasan Pondok Putri Pesantren Tebuireng Kabupaten Jombang. Tempat tersebut berada di Kawasan pondok, dikarenakan ruang gerak santriwati yang tidak diperbolehkan untuk acara di tempat yang jauh. Sehingga dengan pertimbangan keselamatan dan aturan yang berada di pondok kami memutuskan untuk mengadakan PKM ini di sekitar pesantren.

Sasaran dari kegiatan ini adalah santriwati di Pondok Putri Pesantren Tebuireng Jombang yang berjumlah \pm 20 orang. Kegiatan ini dilaksanakan di Masjid Ulul Albab Kawasan Pondok Putri Pesantren Jombang.

\section{PEMBAHASAN}

Pengabdi merasa perlu untuk memperbaiki kondisi di masyarakat berkaitan dengan kepenulisan cerpen. Kinerja pengabdian kepada masyarakat PT dapat menumbuhkan keterampilan menulis cerpen santriwati melalui penugasan membuat cerpen yang dikerjakan santriwati dengan harapan terciptanya budaya menulis cerpen di Pondok Pesantren Putri Tebuireng Jombang. Pengabdian kepada masyarakat ini menggunakan metode ceramah dan praktik. Melalui kegiatan tersebut masalah-masalah kepenulisan cerpen dapat dikaji, ditingkatkan dan dituntaskan, sehingga diharapkan dapat menciptakan sebuah budaya belajar (learning culture) di kalangan santriwati di Pondok Pesantren Putri Tebuireng Jombang.

Tindakan yang dilakukan oleh pengabdi adalah mengadakan apresiasi berupa tanya jawab tentang berbagai macam cerpen remaja yang digemari para santriwati. Tujuan dari apresiasi ini adalah menggali pengetahuan dan pengalaman santriwati tentang berbagai macam cerpen remaja yang pernah dilihat dan memberikan penjelasan mengenai kegiatan belajar mengajar yang hendak dilaksanakan, yaitu mengenai menulis cerpen melalui teknik pengandaian diri sebagai tokoh dalam cerita dengan media audio visual.metode tersebut dikenal sebagai psikologi komunitas. Psikologi komunitas merupakan sebuah cara untuk meningkatkan serta memberdayakan sebuah kelompok sehingga dapat memajukan kesejahteraan dalam kehidupan (Maton, 2004:4). Hal ini menjadikan cerpen sebagai alat guna meningkatkan kesejahteraan para santriwati pondok putri Tebuireng khususnya, masyarakat pada umumnya. Hal itu dilakukan kolaborasi antara pemateri dengan dengan warga dalam sebuah komunitas (Dalton, 2007:6).

Cerpen merupakan kependekan dari cerita pendek. Seperti namanya, karya tulis satu ini cenderung singkat isinya. Dibanding tulisan-tulisan lainnya yang lebih panjang seperti novel, cerpen cenderung lebih padat dan langsung pada tujuan. Cerpen dibatasi panjang penulisannya. Sebuah definisi klasik dari cerpen adalah harus dapat dibaca dalam waktu sekali duduk. Sementara definisi lainnya menyebutkan panjang cerpen tidak lebih dari 20.000 kata dan tidak kurang dari 1000 kata. Ada pula yang menyebutkan panjang cerpen paling tidak mencapai 10.000 kata. Cerpen yang panjangnya mencapai 10.000 kata banyak ditulis oleh cerpenis amerika serikat, daerah eropa pada tahun 1940-1960an (Pranoto, 2007:13-14).

Cerpen pada umumnya adalah suatu bentuk karangan fiksi. Genre yang paling banyak diterbitkan adalah fiksi seperti fiksi ilmiah, fiksi horor, fiksi detektif, dan lain sebagainya. Namun, Cerpen kini juga mencakup bentuk nonfiksi seperti catatan perjalanan, prosa lirik dan varian-varian pasca modern serta non-fiksi seperti fikto-kritis atau jurnalisme baru. Bagi pemula yang akan mulai menulis cerpen, ada baiknya jika kamu mulai mengetahui cara membuat cerpen agar 
nantinya cerpenmu dapat tersusun dengan baik.

Penulisan cerpen menurut Sumoharjo (2001:70) mempunyai beberapa tahapan penulisan 1. Tahapan persiapan, 2 tahap inkubasi, 3. Tahap inspirasi, 4. Tahapan penulisan. Penulisan cerpen mempunyai berbagai macam tujuan atau manfaat diantaranya meningkatkan kecerdasan, meningkatkan daya kreatif dan inovatif, menumbuhkan keberanian, mendorong kemauan sesorang untuk melakukan kegiatan menulis (Yunus, 2002:4).

Para santriwati diajarkan untuk menulis cerpen dengan metode tersebut. Diharapkan para santri dapat mengaplikasikan pelatihan tersebut di pondok, sehingga para santri dapat mengisi waktu luag mereka dengan hal yang positif sekaligus bermanfaat bagi diri mereka. Penulisan cerpen dengan menggunakan psikologi komunitas ini diharapkan memancing daya kreativitas santriwati pondok pesantren putri Tebuireng untuk menulis secara kritis, sesuai dengan keadaan yang berada di lingkungan mereka. Hal tersebut tentunya membutuhkan niat yang besar serta pendampingan terhadap para santriwati. Pemateri sangat minim dalam mengakses ke dalam pesantren, karena tidak diperbolehkan bagi pria untuk masuk ke dalam pesantren. Namun hal tersebut sudah dapat kita tanggulangi dengan adanya pemateri serta mahasiswa putri yang dapat masuk serta mengakses. Sehingga pemantauan terhadap proses penulisan cerpen dengan metode psikologi komunitas dapat dilaksanakan dengan lancer dan baik.

\section{SIMPULAN}

Pelatihan penulisan cerpen dengan metode psikologi komunitas sangat diperlukan bagi masyarakat guna meningkatkan daya kreativitas serta diharapkan dapat meningkatkan serta sebagai penambah penghasilan. apabila penulisan cerpen ini dilakukan di pesantren putri tebuireng diharapkan mampu untuk meningkatkan kreativitas santriwati serta menambah bekal bagi mereka yang mana mereka tinggal jauh dari kampung halaman.

Pengabdian kepada masyarakat ini dilakukan oleh tim yang terdiri dari beberapa anggota. Keanggotaan yang melakukan PKM penulisan cerpen dengan metode psikologi komunitas antara lain Alfian Setya Nugraha, Rusli Ilham Fadli, Resdianto Permata Raharjo, Raras Hafida, Agus Sulton. Dari kelima orang tersebut merupakan dosen prodi Pendidikan Bahasa Indonesia Universitas Hasyim Asyari Tebuireng Jombang.

\begin{tabular}{|c|c|c|c|c|c|c|c|}
\hline \multirow{2}{*}{ No } & \multirow{2}{*}{ Jenis Kegiatan } & \multicolumn{6}{|c|}{ Bulan } \\
\hline & & 7 & 8 & 9 & 10 & 11 & 12 \\
\hline 1. & $\begin{array}{l}\text { Persiapan } \\
\text { Pengumpulan } \\
\text { Data }\end{array}$ & & & & & & \\
\hline 2. & $\begin{array}{l}\text { Pengumpulan } \\
\text { bahan } \\
\text { penelitian }\end{array}$ & & & & & & \\
\hline 3. & $\begin{array}{l}\text { Pengolahan } \\
\text { Data }\end{array}$ & & & & & & \\
\hline 4. & $\begin{array}{l}\text { Persiapan } \\
\text { pembuatan } \\
\text { laporan } \\
\text { Penelitian }\end{array}$ & & & & & & \\
\hline 5. & $\begin{array}{l}\text { Menyusun } \\
\text { Penulisan } \\
\text { Laporan }\end{array}$ & & & & & & \\
\hline 6. & $\begin{array}{l}\text { Penyerahan } \\
\text { Laporan } \\
\text { Penelitian }\end{array}$ & & & & & & \\
\hline
\end{tabular}


Moh.Yamin, 2010. Manajemen Mutu Kurikulum Pendidikan: Panduan Menciptakan Mutu Pendidikan Berbasis

\section{DAFTAR PUSTAKA}

Bambang Sugiarto. 2008. Humanisme dan Humaniora (Relevansinya dengan Pendidikan), Yogyakarta-Bandung: Jalasutra,

Dalton, James $\mathrm{H}$ and Maurice J.Elias, Abraham Wandersman. 2007. Community Psychology: Linking Individuals and communities, $2^{\text {nd }}$ edition. USA:Thomson Wasdworth.

Yunus, Suparno. 2002. Keterampilan dasar menulis. Jakarta: universitas terbuka.
Kurikulum Yang Progresif Dan Inspiratif, Diva Press.

Pranoto. 2007. Kamus Besar Bahasa Indonesia. Jakarta: Gramedia.

Sukardjo, M. 2009. Landasan Pendidikan (konsep dan Aplikasinya), Jakarta: PT. Raja Grafindo Persada,

Sumoharjo, Jakob. 2001. Seni Pertunjukan Indonesia. Bandung: STSI Press. 